\title{
Intestinal parasitosis, anaemia and risk factors among pre-school children in Tigray region, northern Ethiopia
}

Araya Gebreyesus Wasihun ${ }^{1 *}$, Mekonen Teferi², Letemichal Negash", Javier Marugán ${ }^{3}$, Dejen Yemane ${ }^{4}$, Kevin G. McGuigan ${ }^{5}$, Ronan M. Conroy ${ }^{6}$, Haftu Temesgen Abebe ${ }^{7}$ and Tsehaye Asmelash Dejene ${ }^{8}$

\begin{abstract}
Background: Intestinal parasitic infections (IPIs) and anaemia are major health problems. This study assessed the prevalence of intestinal parasitic infections, anaemia and associated factors among pre-school children in rural areas of the Tigray region, northern Ethiopia.

Methods: A community based cross-sectional study was conducted among 610 pre-school children in rural communities of Northern Ethiopia from June 2017 to August 2017. Stool specimens were examined for the presence of trophozoites, cysts, oocysts, and ova using direct, formal-ethyl acetate concentration, Kato-Katz, and Ziehl-Neelsen techniques. Haemoglobin was measured using a HemoCue spectrometer.

Results: Among the 610 participating pre-school children in the study, the prevalence of IPIs and anaemia were 58\% (95\% conference interval (Cl): 54.1-61.9\%) and 21.6\% (95\% Cl: 18.5-25.1\%), respectively. Single, double, and triple parasitic infections were seen in 249 (41, 95\% Cl: 37-45\%), 83 (14, 95\% Cl: 11-17\%), and 22 (3.6, 95\% Cl: 2.4-5.4\%) children, respectively. Of the seven intestinal parasitic organisms recorded from the participants, Entamoeba histolytical dispar was the most prevalent 220 (36.1\%) followed by Giardia lamblia 128 (20.1\%), and Hymenolepis nana 102 (16.7\%). Mixed infections were common among G. lamblia, E. histolytica/dispar and Cryptosporidium spp. oocyst. Intestinal parasitic infection prevalence increased from $47 \%$ in children aged 6-11 months to $66 \%$ in those aged $48-59$ months; the prevalence ratio (PR) associated with a one-year increase in age was 1.08 (95\% Cl: 1.02-1.14, $p=0.009)$. Ageadjusted prevalence was higher in children who had been dewormed ( $\mathrm{PR}=1.2 ; 95 \% \mathrm{Cl}: 1.00-1.4, p=0.045)$, and lower in households having two or more children aged under five $(P R=0.76,95 \% \mathrm{Cl}: 0.61-0.95, p=0.015)$. Anaemia rose from $28 \%$ in children aged 6-11 months to $43 \%$ in those aged 12-23 months, then fell continuously with age, reaching $7 \%$ in those aged $48-59$ months. Age adjusted, anaemia was more prevalent in households using proper disposal of solid waste ( $P R=1.5,95 \% \mathrm{Cl}: 0.1-2.10, p=0.009)$ while eating raw meat $(\mathrm{PR}=0.49,95 \% \mathrm{Cl}: 0.45-0.54, p=0.000)$, any maternal education $(P R=0.6495 \% \mathrm{Cl}: 0.52-0.79, p=0.000)$, and household water treatment $(P R=0.75,95 \%$ Cl: 0.56-1.0, $p=0.044)$ were associated with lower prevalence of anaemia.

(Continued on next page)
\end{abstract}

\footnotetext{
*Correspondence: araya13e25@gmail.com

'Department of Medical Microbiology and Immunology, College of Health Sciences, Mekelle University, Tigray, Ethiopia

Full list of author information is available at the end of the article
}

C C The Author(s). 2020 Open Access This article is licensed under a Creative Commons Attribution 4.0 International License, which permits use, sharing, adaptation, distribution and reproduction in any medium or format, as long as you give appropriate credit to the original author(s) and the source, provide a link to the Creative Commons licence, and indicate if changes were made. The images or other third party material in this article are included in the article's Creative Commons licence, unless indicated otherwise in a credit line to the material. If material is not included in the article's Creative Commons licence and your intended use is not permitted by statutory regulation or exceeds the permitted use, you will need to obtain permission directly from the copyright holder. To view a copy of this licence, visit http://creativecommons.org/licenses/by/4.0/ The Creative Commons Public Domain Dedication waiver (http://creativecommons.org/publicdomain/zero/1.0/) applies to the data made available in this article, unless otherwise stated in a credit line to the data. 
(Continued from previous page)

Conclusions: More than half of the children were infected with intestinal parasites, while anaemia prevalence was concentrated in the 12-23 month age group. This study has identified a number of potentially modifiable risk factors to address the significant prevalence of IPIs and anaemia in these children. Improvements in sanitation, clean water, hand hygiene, maternal education could address both short and long-term consequences of these conditions in this vulnerable population.

Keywords: Intestinal parasitic infections, Anaemia, Pre-school age children, Risk factors, Ethiopia

\section{Background}

Intestinal parasitic infections (IPIs) are an important cause of morbidity and mortality worldwide [1] affecting about 3.5 billion people globally [2]. IPIs are endemic in resourcelimited regions due to high population density, low access to improved water sources, low latrine availability, poor hygiene conditions, low health awareness, and limited economic resources [3, 4]. Helminths such as Ascaris lumbricoides, Hookworm, Strongloides stercolaris and Trichuris trichiura, and enteric protozoan parasites such as Entamoeba histolytica, Giardia lamblia and Cryptosporidium spp. cause high incidences of health problems especially in children in low to middle income countries [5].

Children due to their immature immune systems and frequent exposure to unhygienic environments are at high risk for IPI including helminths [6] and protozoa [7]. These infections are common during the period of life most critical for physical and cognitive development, hence are linked with an increased risk of childhood malnutrition and growth deficits [8]. Poor health in children also results in deficits in cognitive development and educational achievements [9].

As with IPIs, anaemia remains a public health problem affecting both developing and developed countries with major consequences for human health as well as social and economic development [10]. Globally, 2011 data indicate that $43 \%$ of children under-five were anaemic, with a higher prevalence in the developing world, specifically South Asia and East Africa, being 58 and 55\%, respectively [11]. Sub-Saharan Africa is one of the most affected regions with $54 \%$ of children under-five suffering from anaemia [12]. The causes of anaemia include folate and iron deficiencies [13], malaria [14], infections (e.g., intestinal helminths), and diarrhoea [15]. Childhood anaemia has many irreversible impacts: it impairs physical growth [16], impairs immune function, increases susceptibility to infections [17] and weakens motor development leading to reduced cognitive ability [18] and short or long term mortality in severe cases [13].

The 2016 Demographic and Health Survey of Ethiopia (EDHS) report showed that the national prevalence of anaemia among children aged 6 to 59 months was $57 \%$ [19], which exceeds the $40 \%$ threshold set by the World Health Organization (WHO) [13]. The EDHS report of anaemia prevalence in the Tigray regional state $(54 \%)$ is marginally below the national average (57\%) [19].

Most studies conducted in Ethiopia on the prevalence of IPIs are on school-age children. Studies conducted among pre-school age children have shown IPI prevalence up to $85.1 \%$ [20]. Similarly, national studies on anaemia prevalence report prevalence from 32 to $37 \%$ [21]. These studies, however, are focused on either soil transmitted helminths alone [22] or symptomatic hospitalized children [23], or investigated anaemia alone. Furthermore, none of the above studies used modified Ziehl-Neelsen techniques to detect Cryptosporidium spp., the second most causative agent of diarrhea among children under five next to rotavirus [24].

There is scarcity of data on the prevalence of IPI, anaemia, and their associated risk factors among pre-school children in the study area. However, the prevalence is expected to be high given the poverty, poor hygiene, hot/humid tropical climate and lack of access to potable water. Establishing baseline prevalence and elucidating potentially modifiable risk factors for IPI and anaemia would help public health planners, policy makers and implementers to plan and design appropriate intervention strategies to reduce associated morbidity and mortality among pre-school children.

\section{Methods}

Study area, design, study population, setting and period This community based cross-sectional study was carried out from June-August 2017 in rural communities surrounding the Mekelle zone, Tigray region, northern Ethiopia. Four sites namely: Serawat, Harena, Maynebri and Tsuwanet were selected using a simple random lottery method from the total of 32 administrative unit found in the surrounding districts. The population typically experience poor sanitation, poor access to safe drinking water, and low socioeconomic status. More details have been previously described elsewhere [25].

\section{Sample size and sampling technique}

The sample size of the study was determined using a single population proportion formula, considering an estimate of $24.3 \%$ expected prevalence of IPIs among children younger than 5 years old. Assuming any particular outcome to be within a 5\% marginal error and a $95 \%$ confidence interval of certainty, the final sample size with a design effect of two is 570 (based on Statulator 
website, http://statulator.com/SampleSize/ss1P.html). To allow for data loss, 610 participants were recruited.

We used a multistage stratified sampling technique to identify study participants after the kebelles (a kebelle is the smallest local government administrative unit in Ethiopia) were stratified. In the selected kebelles, 2674 children aged 6-59 months were identified with their respective households using the registration at health posts and through the health extension workers.

We allocated the calculated sample proportionally to the selected kebelles based on the total number of households with children aged 6-59 months in each kebelle. Study participants were then identified using simple random sampling of the households. In cases where households had more than one eligible child, the eldest child was included. Accordingly, the distribution of households with respect to the kebelles was, 133 from Tsawnet, 142 from Harena, 158 from Serawat, and 177 from Mynebri.

\section{Data collection}

After written consent was obtained from mothers or guardians of eligible children, socioeconomic, environmental, behavioural and health related data were collected using a structured questionnaire (translated from English and printed in the local Tigrigna language). Data were collected using a face-to-face administrated questionnaire and an observation method by trained data collectors, under the supervision of the principal investigators. Child hand cleanness and nail status in addition to toilet availability were assessed by direct observation.

\section{Out come variables}

IPIs and anaemia among children aged 6-59 months (pre-school children).

\section{Predictor variables \\ Socio-economic variables}

Gender and age of the study child, mother's/guardian's educational status and occupation, family size, family income, number of children 6-59 months in the household.

\section{Environmental and behavioral variables}

Consumption of raw vegetables, child contact with pet animals, child deworming, habit of playing in soil, shoe wearing habit, child hand cleanliness and fingernail status. Use of soap for hand washing, water source, use of household water treatment, latrine availability, and type of drinking water source.

\section{Faecal sample collection}

Following the completion of consent and questionnaire, a clean, wide screw-capped plastic stool cup, labelled with names was provided to each mother/guardian. They were requested to bring about $10 \mathrm{~g}$ (thumb size) fresh stool from their child to the nearby health posts the following day within 10-30 min of passage. Participants who were not able to provide a sample on the first day were asked again on the following day.

\section{Haemoglobin $(\mathrm{Hb})$ measurement}

Finger-prick blood specimens were obtained from participants to assess $\mathrm{Hb}$ levels using a HemoCue analyser in the health post (HemoCue Hb 201z, Sweden) (49). The apparatus was calibrated daily using the reference micro cuvettes as indicated by the manufacturer. Definition and classification of anaemia were according to the WHO cut-offs [26].

\section{Parasitological analysis}

Stool specimens were analyzed at the respective health posts by three trained laboratory technicians using direct saline wet mount, formalin ethyl acetate concentration technique [27] and single Kato-Katz technique (thick smear $41.7 \mathrm{mg}$ ). For the detection of Cryptosporidium spp. oocysts, modified Ziehl-Neelsen (MZN) staining was performed. Kato-Katz, wet mount preparations and modified Ziehl-Neelsen were analysed within $1 \mathrm{~h}$ of preparation in each respective health posts to detect hookworm eggs, protozoa parasites (E. histolytica/dispar and G. lamblia), and Cryptosporidium spp., respectively.

The remaining stool specimens were transported in screw-capped cups in $10 \%$ formalin to Mekelle University Medical Microbiology Laboratory and were examined using the concentration method within $8 \mathrm{~h}$ after collection. After $72 \mathrm{~h}$, Kato-Katz preparations were reexamined to detect helminth ova. A child was categorized as infected if the stool sample was positive for any parasite by any of the methods used. To ensure quality, each slide was examined twice by two of the three experienced laboratory technician independently.

\section{Quality control}

To control our data quality, $10 \%$ of the total positive specimens were randomly selected and re-examined by three experienced laboratory technicians who did not have any information about the previous results. As results among the laboratory technicians were similar, the results of the new laboratory examinations were therefore used as quality control.

\section{Data analysis}

Data were analysed with Stata Release 15. Confidence intervals for prevalence were calculated using the AgrestiCoull formula. Negative binomial regression was used to model prevalence rate ratios. Prevalence rate ratios have several advantages over odds ratios. The first is that they are simple to interpret; they directly compare prevalence, so a prevalence ratio of 2 means that prevalence is twice 
as high. Second, prevalence ratios, but not odds ratios, have a mathematical property called collapsibility; this means that the size of the risk ratio will not change if adjustment is made for a variable that is not a confounder [28]. All reported $p$-values were two-tailed, and statistical values were considered significant when $p<0.05$.

\section{Results}

\section{Characteristics of participants in the study}

Most mothers (79\%) had one under-five child. According to the results of the study, $58 \%$ mothers and $44.9 \%$ of the fathers were illiterate (unable to read or write). As to the shoe wearing habit of the children, majority, 587 (96.2\%) of them wore shoes either sometimes or regularly. Only $32(5.2 \%)$ of the children consumed raw vegetables at a regular basis. Regarding the child deworming status, 395 (68.3\%) of the children were dewormed for STH. Household water treatment (any means) was practiced among 150 (24.6\%) households. Regarding latrine availability, $59.7 \%$ of the households had their own latrine facilities (Table 1).

\section{Prevalence of intestinal Parasitosis and anaemia}

Among the 610 participating pre-school children, 354 (58\%) (95\% CI: 54.1-62.1\%) were infected by one or more parasitic organism. Single, double, and triple parasitic infections were seen in 249 (40.8\%), 83 (13.6\%), and 22 (3.6\%) children, respectively. Seven different intestinal parasitic organisms were detected with $E$. histolytica/dispar the most prevalent 220 (36.1\%) followed by G. lamblia $128(20.1 \%)$ and H. nana 102 (16.7\%). Mixed infections were common among children positive for G. lamblia, $E$. histolytica/dispar and Cryptosporidium spp. Soil transmitted helminthic infections either alone or with other intestinal parasite were identified in 104 (17.1\%) of the children with $H$.nana 102 (16.7\%) being dominant while Ascaris, hookworm and Trichuris infections were very rare or absent. The prevalence of any type of anaemia was $21.6 \%$ (95\% CI: 18.5-25.1\%) (Table 2).

\section{Socio-demographic and health related factors associated with IPIs and Anaemia}

Prevalence of intestinal parasitic infection rose from 50\% in children aged under 2 years, to $66 \%$ in children aged 4 to 5 years. The prevalence rate increased by $7.8 \%$ per year over the age range studied (negative binomial regression, incidence rate ratios (IRR) $=1.078, p=0.009$ ). In contrast to IPIs, prevalence of anaemia rose from $28 \%$ in those aged 6 months to 1 year to $44 \%$ in children aged 1 year. Thereafter it declined sharply with age to reach $7 \%$ in those aged 4 years (Table 1 ).

Because prevalence of parasites is associated with age, we used negative binomial regression adjusted for age to calculate prevalence rate ratios associated with each of the associated risk factors. Adjusted for age, prevalence of IPI was higher in children with current gastro intestinal (GI) symptoms $(p=0.001)$, who had diarrhea in the previous 14 days $(p=0.000)$, and who had been dewormed $(p=0.045)$. Prevalence was however, lower in households with two or more children aged under 5 $(p=0.015)$ (Table 3).

\section{Factors associated with anaemia among pre-school age children}

Eating raw meat $(\mathrm{p}=0.000)$, any maternal education $(\mathrm{p}=$ $0.000)$, and household water treatment $(p=0.044)$, were associated with lower prevalence ratio of anaemia, when adjusted for age. On the other hand, presence of domestic animals in the house $(p=0.006)$, and proper disposal of solid waste $(p=0.009)$ were both associated with increased risk (Table 4). There was a $25 \%$ prevalence of anaemia in the 256 children who had no intestinal parasites, compared with a $19 \%$ prevalence in the 354 who had any parasite. This association was not statistically significant $(p=0.085$, Chi-squared test). Adjusting prevalence for site and child's age did not substantively alter this finding.

\section{Discussion}

IPI prevalence (58\%) in our study was comparable with previous reports from Pakistan 52.8\% [29] and Nigeria, 51.4\% [30], though lower than studies conducted in south Ethiopia, 85.1\% [20], Cuba, 71.1\% [31] and Malaysia, 76.5\% [32]. However, our prevalence is higher than previous similar studies conducted in east Ethiopia, 24.3\% [22], south Ethiopia 4.9\% [34], Amhara region, 15.5\% [33], Oromia region, 49.6\% [34], Shoa, Ethiopia 17.4\% [35] and Northwest Ethiopia 25.8\% [36]. Others have reported lower IPI prevalence in Nigeria, 13.7\% [37], Iran, 26.6\% [38], Uganda, 26.5\% [39], Saudi Arabia, 17.7\% [40] and Yemen, 30.9\% [41]. These reported differences in IPI prevalence might be due to the difference in parasitological methods used, geographical location, level of environmental sanitation, drinking water source, season, family education, personal- hygiene, parental socioeconomic and cultural difference of the study participants.

One explanation for the high IPI prevalence in this study could be because of seasonal variation. Data collection for our study took place during the rainy season in Ethiopia, other studies [32, 35, 40,42] were conducted in the dry season. Seasonal variation may be explained by increased contamination of water sources (e.g., rivers, streams, and wells) with human excreta from open defecation which is the main risk factor for diarrhoeal disease and IPIs, especially children who routinely play in the an unhygienic environment [25]. In addition, as $77 \%$ of households in our study used unprotected water sources, the main factor for faecal-oral transmitted disease such as IPIs, this may also contribute to the high IPI prevalence. 
Table 1 Prevalence of IPIs and Anaemia among 610 pre-school children in Tigray, Ethiopia, 2017

\begin{tabular}{|c|c|c|c|c|}
\hline \multicolumn{2}{|l|}{ Risk factors Categories } & \multirow{2}{*}{$\begin{array}{l}\text { No }(\%)(n=610) \\
284(46.6)\end{array}$} & \multirow{2}{*}{$\begin{array}{l}\text { IPI Prevalence \% } \\
57.4\end{array}$} & \multirow{2}{*}{$\begin{array}{l}\text { Anaemia Prevalence \% } \\
19.7\end{array}$} \\
\hline$\overline{\text { Sex }}$ & Girls & & & \\
\hline & Boys & $326(53.4)$ & 58.6 & 23.3 \\
\hline \multirow[t]{5}{*}{ Age (months) } & $6-11$ & $32(5.3)$ & 46.9 & 28.1 \\
\hline & $12-23$ & $108(17.7)$ & 50.0 & 43.5 \\
\hline & $24-35$ & $160(26.2)$ & 54.4 & 26.9 \\
\hline & $36-47$ & $149(24)$ & 61.1 & 14.8 \\
\hline & $48-59$ & $161(26.4)$ & 66.5 & 6.8 \\
\hline \multirow[t]{3}{*}{ The habit of a child playing in soil } & Never & $23(3.8)$ & 52.2 & 30.4 \\
\hline & Sometimes & $135(22.1)$ & 54.1 & 25.9 \\
\hline & Regularly & $452(74.1)$ & 59.5 & 19.9 \\
\hline \multirow[t]{3}{*}{ Child shoe wearing habit } & Never & $49(8)$ & 59.2 & 22.4 \\
\hline & Sometimes & $202(33.1)$ & 56.4 & 20.3 \\
\hline & Regularly & $359(58.9)$ & 58.8 & 22.3 \\
\hline \multirow[t]{3}{*}{ Family monthly income in Ethiopian birr } & $<500$ birr & $99(16.2)$ & 62.6 & 25.3 \\
\hline & 500-2000birr & $451(73.8)$ & 57.6 & 22.4 \\
\hline & $>2000$ birr & $60(9.8)$ & 53.3 & 10.0 \\
\hline \multirow[t]{3}{*}{ Consumption of raw vegetables } & Never & $106(17.4)$ & 58.5 & 17.0 \\
\hline & Sometimes & $472(77.4)$ & 57.6 & 22.5 \\
\hline & Always & $32(5.2)$ & 62.5 & 25.0 \\
\hline \multirow[t]{2}{*}{ Child fingernail status } & Untrimmed & $295(48.4)$ & 59.3 & 19.3 \\
\hline & Trimmed & $315(51.6)$ & 56.8 & 23.8 \\
\hline \multirow[t]{2}{*}{ Child hand cleanness } & Unclean & $243(39.8)$ & 63.4 & 16.5 \\
\hline & Clean & $367(60.2)$ & 54.5 & 25.1 \\
\hline \multirow[t]{3}{*}{ Child hand washing habit with soap before a meal } & Never & $80(13.1)$ & 60.0 & 23.8 \\
\hline & Sometimes & $344(56.4)$ & 57.3 & 20.9 \\
\hline & Always & $186(30.5)$ & 58.6 & 22.0 \\
\hline \multirow[t]{2}{*}{ Number of children in the house } & $<4$ & $144(23.6)$ & 59.4 & 22.5 \\
\hline & $\geq 4$ & $466(76.4)$ & 53.5 & 18.8 \\
\hline \multirow[t]{2}{*}{ Number of under five children in the house } & 1 & $482(79)$ & 61.0 & 20.7 \\
\hline & 2 and more & $128(21)$ & 46.9 & 25.0 \\
\hline \multirow[t]{3}{*}{ Mother's educational level } & Illiterate & $354(58)$ & 61.6 & 24.0 \\
\hline & Primary school & $193(31.6)$ & 53.9 & 17.6 \\
\hline & Secondary school & $54(8.9)$ & 50.8 & 20.6 \\
\hline \multirow[t]{3}{*}{ Mother's/guardian's Occupation } & House wife & $562(92.1)$ & 58.2 & 22.2 \\
\hline & Governmental employee & $19(3.1)$ & 42.1 & 15.8 \\
\hline & Self-employed & $29(4.8)$ & 65.5 & 13.8 \\
\hline \multirow[t]{2}{*}{ Household water source } & Unprotected & $470(77)$ & 58.9 & 20.9 \\
\hline & Protected & $140(23)$ & 55.0 & 24.3 \\
\hline \multirow[t]{2}{*}{ Solid waste disposal } & Improper & $559(91.7)$ & 62.7 & 15.7 \\
\hline & Proper & $51(8.3)$ & 57.6 & 22.2 \\
\hline \multirow[t]{2}{*}{ Use household water treatment } & No & $460(74.4)$ & 55.7 & 23.3 \\
\hline & Yes & $150(24.6)$ & 65.3 & 16.7 \\
\hline \multirow[t]{2}{*}{ Toilet availability } & No & $246(40.3)$ & 58.1 & 18.7 \\
\hline & Yes & $364(59.7)$ & 58.0 & 23.6 \\
\hline
\end{tabular}


Table 1 Prevalence of IPIs and Anaemia among 610 pre-school children in Tigray, Ethiopia, 2017 (Continued)

\begin{tabular}{|c|c|c|c|c|}
\hline Risk factors Categories & & No $(\%)(n=610)$ & IPI Prevalence \% & Anaemia Prevalence \% \\
\hline \multirow[t]{3}{*}{ Child contact with pet animals } & Never & $366(60)$ & 56.0 & 24.0 \\
\hline & Sometimes & $149(24.4)$ & 62.4 & 19.5 \\
\hline & Regularly & $95(15.6)$ & 58.9 & 15.8 \\
\hline \multirow[t]{2}{*}{ Child deworming $(n=578)$} & No & $183(31.7)$ & 49.7 & 27.3 \\
\hline & Yes & $395(68.3)$ & 61.6 & 19.2 \\
\hline \multirow[t]{2}{*}{ Diarrhea in the last 14 days } & No & $437(71.6)$ & 53.8 & 21.5 \\
\hline & Yes & $173(28)$ & 68.8 & 22.0 \\
\hline \multirow[t]{2}{*}{ Current Gl symptoms } & No & $475(77.9)$ & 53.9 & 21.5 \\
\hline & Yes & $135(22)$ & 72.6 & 22.2 \\
\hline
\end{tabular}

Table 2 Intestinal parasite and anaemia among 610 pre-school children in the Tigray region of Northern Ethiopia, 2017

\begin{tabular}{ll}
\hline Variables & No (\%) \\
\hline Children with intestinal parasite(s) detected & $354(58)$ \\
Number of single parasitic infections & $249(40.8)$ \\
Number of double parasitic infections & $83(13.6)$ \\
Number of triple parasitic infections & $22(3.6)$ \\
Haemoglobin level & \\
$\quad$ Normal & $478(78.4)$ \\
Anaemia & $132(21.6)$ \\
Infection type & \\
Protozoa & \\
E. histolytica/dispar & $125(20.5)$ \\
G. lamblia & $52(8.5)$ \\
Cryptosporidium spp. & $11(1.8)$ \\
E. vermicularis & $2(0.3)$ \\
Helminths & \\
H. nana & $59(9.7)$ \\
A. lumbricoides & $1(0.2)$ \\
S. stercoralis & $1(.2)$ \\
Double infection & \\
G. lamblia + E. histolytica/dispar & \\
G. lamblia + H. nana & $14(2.3)$ \\
E. histolytica/dispar + H. nana & \\
G. lamblia + Cryptosporidium spp. Oocyst & $2(7.3(7.2)$ \\
E. histolytica/dispar + E. vermicularis & $8(1.3)$ \\
Triple infection & $27(4.7)$ \\
G. lamblia + E. histolytica/dispar + H. nana \\
E. histolytica/dispar + G. lamblia + Cryptosporidium spp. \\
\hline
\end{tabular}

Another possible reason for the high prevalence of IPIs in our study is the laboratory methods we employed. We used the modified Ziehl Nelson method to detect Cryptosporidium spp., whereas the other studies except [38, 43] did not. Furthermore, some studies isolated only the soiltransmitted helminths (STH) and not protozoa which would artificially decrease IPI prevalence [22, 32, 33, 39].

E. histolytica, G. lambilia and C. parvum were the most prevalent protozoan parasites in our study cohort. The high prevalence of E. histolytica/dispar (36.1\%) in our study is in agreement with previous reports [44]. Consequences of childhood E. histolytica infection include malnourishment, anaemia and stunted growth [45]. However, others have reported G. lamblia [41, 46] and C. parvum [47] as the dominant parasites. The difference in prevalence of enteric protozoa may be due to differences in contamination of drinking water sources, availability of toilets, handwashing and consumption of raw vegetables of the study participants.

Helminthic intestinal parasites, particularly soil transmitted helminths (STHs), commonly infect children in low to middle-income countries. In our study, helminthic infections were identified in 104 (17.1\%) of the children with $H$.nana 102 (16.7\%) being dominant while Ascaris, hookworm and Trichuris infections were very rare or absent. The low STH incidence in our study might be due to the initiation of a national deworming program, as the majority, $68.3 \%$ of the children were dewormed during the data collection time and deworming is given on a regular basis. The relatively high prevalence of wearing shoes either regularly or sometimes and low prevalence of consumption of raw vegetables may also partially explain the low STH prevalence. Besides, the prevalence of STH might also be due to differences in environmental factors such as climate, topography [48], surface temperature, altitude, soil type and rainfall [49].

Our study shows that dewormed children were more infected with IPIs than their counter part which appears counter-intuitive. This could be due to the fact that the prevalence of STHs, where deworming is recommended, 
Table 3 Associated Risk factors for prevalence of IPIs among 610 pre-school children in the Tigray, Ethiopia, 2017

\begin{tabular}{|c|c|c|c|}
\hline Risk factor & Prevalence ratio & $95 \% \mathrm{Cl}$ & $p$ value \\
\hline \multicolumn{4}{|l|}{ Socio-demographic characteristics } \\
\hline Male sex & 1.0 & $0.89-1.20$ & 0.714 \\
\hline $2+$ under five children in the house & 0.76 & $0.61-0.95$ & $0.015^{* *}$ \\
\hline Any education & 0.89 & $0.74-1.10$ & 0.186 \\
\hline 4 or more children & 0.93 & $0.72-1.20$ & 0.611 \\
\hline \multicolumn{4}{|l|}{ Hygienic and environmental characteristics } \\
\hline Child's hands clean & 0.89 & $1.0-0.80$ & 0.129 \\
\hline Solid waste disposed of properly & 0.91 & $0.76-1.10$ & 0.327 \\
\hline Water from improved source & 1.0 & $0.85-1.10$ & 0.382 \\
\hline House hold water treatment & 1.2 & $1.0-1.40$ & 0.057 \\
\hline Presence of domestic animals in house & 1.0 & $0.78-1.30$ & 0.939 \\
\hline Soap used in handwashing & 1.0 & $0.89-1.10$ & 0.988 \\
\hline Habit of eating raw meat & 1.0 & $0.75-1.40$ & 0.855 \\
\hline Latrine availability in the house & 1.0 & $0.92-1.10$ & 0.949 \\
\hline Child's fingernails trimmed? & 1.0 & $0.89-1.10$ & 0.588 \\
\hline Eats fruit or raw vegetables & 1.0 & $0.82-1.20$ & 0.798 \\
\hline \multicolumn{4}{|l|}{ Health characteristics } \\
\hline Child in contact with animals & 1.1 & $1.0-1.20$ & 0.230 \\
\hline Any skin disease & 1.1 & $0.95-1.20$ & 0.258 \\
\hline Did the child get dewormed $(N=427)$ & 1.2 & $1.0-1.40$ & $0.045^{* *}$ \\
\hline Diarrhea in the last 14 days & 1.3 & $1.2-1.40$ & $0.000^{* *}$ \\
\hline Current Gl symptoms & 1.3 & $1.1-1.60$ & $0.001^{* *}$ \\
\hline
\end{tabular}

${ }_{* *}^{*}=$ statistically significant. All prevalence ratios are adjusted for age using negative binomial regression

was very small in our study. Whereas, protozoan infection where deworming is not given was the most dominant. A lower prevalence of STH compared with $H$. nana has been previously reported in Peru [50] and in Eastern Ethiopia in elementary school children receiving regular albendazole deworming treatment [51]. This could be probably due to the fact that albendazole has little effect on H. nana unlike Ascaris lumbricoides, Trichuris trichiura and hookworm [52].

Children aged 48-59 months ( $\mathrm{PR}=1.078, p=0.009)$ were more likely to be infected by IPIs compared with younger children. This likely reflects increased risk of IPI exposure from playing activity of the older, more mobile children within unhygienic external environments and hence exposed to faecal-contaminated soil.

IPIs were significantly higher in children with current gastro intestinal (GI) symptoms and in those who had diarrhea in the previous 14 days. This was similar to the report from Iran [53]. This is due to the fact that most of the isolated IPIs in this study, E. histolytica and G.lamblia, are potential causes of diarrhea. Likewise, STHs are usually accompanied by current gastro intestinal (GI) symptoms.
Only a quarter of households used household water treatments, mainly chlorination and boiling. Though not statistically significant, children whose family did not treat their water were 1.2 times $(p=0.057)$ more likely to be infected by IPIs. Chlorination is less expensive, less time consuming and provides residual disinfection against recontamination and significantly reduces diarrhea [54]. However, due to the smell and taste [55], only a few families use chlorination in our study. Similarly, due to the consumption of fuel, time, and lack of residual protection against re-contamination [56], only a few households use boiling. Hence a cheap, point of use technology, such as solar disinfection (SODIS), which overcomes these limitation is required by such communities to tackle the consumption of unsafe drinking water.

The prevalence of childhood anaemia among pre-school children in our study was $21.6 \%$, which is comparable with studies from south central Ethiopia, 28.2\% [57], Kenya, 25\% [58], Malaysia, 26.2\% [32], and Brazil 28.9\% [59]. Our study was, however, lower than other reports from Ethiopia, 37.3-42.2\% [60, 61], the 2016 Ethiopian Health Demographic Survey, 57\% [19], the EDHS anaemia prevalence of the Tigray regional state, 54\% (19) and the WHO classification for anaemia, 40\% [13]. 
Table 4 Risk factors for anaemia among 610 pre-school children in the Tigray, Ethiopia, 2017

\begin{tabular}{|c|c|c|c|}
\hline Risk factors & Prevalence ratio & $95 \% \mathrm{Cl}$ & P-value \\
\hline Habit of raw meat eating of the child & 0.49 & $0.45-0.54$ & $0.000^{* *}$ \\
\hline 4 or more children & 0.64 & $0.39-1.00$ & 0.075 \\
\hline Any maternal education & 0.64 & $0.52-0.79$ & $0.000^{* *}$ \\
\hline House hold water treatment & 0.75 & $0.56-1.00$ & $0.044^{* *}$ \\
\hline Soap used in handwashing & 0.85 & $0.64-1.10$ & 0.279 \\
\hline Child in contact with animals & 0.87 & $0.6-1.20$ & 0.399 \\
\hline Any skin disease & 0.95 & $0.56-1.60$ & 0.839 \\
\hline Diarrhea in the last 14 days & 1.0 & $0.66-1.40$ & 0.832 \\
\hline Current Gl symptoms & 1.0 & $0.59-1.60$ & 0.898 \\
\hline Did the child get dewormed $(N=427)$ & 1.0 & $0.86-1.20$ & 0.891 \\
\hline Water from improved source & 1.0 & $0.82-1.30$ & 0.752 \\
\hline Child's fingernails trimmed & 1.1 & $1.0-1.20$ & 0.077 \\
\hline Male sex & 1.1 & $1.0-1.30$ & 0.134 \\
\hline Child's hands clean & 1.2 & $0.87-1.60$ & 0.280 \\
\hline Latrine availability in the house & 1.2 & $0.84-1.70$ & 0.308 \\
\hline Number of under-five children in the house & 1.3 & $0.92-1.90$ & 0.129 \\
\hline Eats fruit or veg raw & 1.4 & $0.91-2.00$ & 0.133 \\
\hline Presence of domestic animals in house & 1.5 & $1.1-2.00$ & $0.006^{* *}$ \\
\hline Solid waste disposed of properly & 1.5 & $1.1-2.10$ & $0.009^{* *}$ \\
\hline
\end{tabular}

** Statistically significant. All prevalence ratios are adjusted for age using negative binomial regression

Likewise, studies performed outside Ethiopia have reported higher anaemia prevalence including those conducted in Brazil, 32.8\% [62], Uganda, 37.2\% [14], Nigeria, 38.6\% [63], Bangladesh, 51.9\% [64], Senegal, 53.4\% [65], West Africa, 51.8\% [66], Tanzania, 47.6\% [67] and Brazil, 45.1\% [62].

Possible reasons for the variation in anaemia prevalence could be due to differences in maternal education [57] concomitant childhood malaria superinfection [55], family income [58], drinking water source [51], personal-hygiene [68] and STH infections [54, 57]. For example, the high anaemia rate in the studies such as Tanzania, Kenya, Senegal, Uganda, south Ethiopia, was due to concomitant malaria infection. Seasonality may have also affected the anaemia prevalence in our study as malaria prevalence is usually low during the rainy season [69] where our data collection time was from June-August, the rainy season of Ethiopia. In addition, our study participants were from the community rather than from health institutions, and the prevalence of $\mathrm{STH}$, the main cause of anaemia $[58,70]$ was very low in our study.

In this study, children whose mothers were not educated were significantly anaemic compared their counter parts. This was similar with the study conducted in Tanzania [71]. This protective benefit of maternal education could be related to an increased knowledge for adequate healthcare and nutrition for children hence its possibility for decreasing the risk of anaemia. Similarly children who eat meat were less anaemic compared to those who don't eat meat. This was supported by a study from Israel [72]. This is due to the fact that meat is a good source of Iron; hence without enough iron, less hemoglobin and fewer red blood cells are made, leading to anaemia. It should be also noted that anaemia has a variety of causes though $50 \%$ of all cases is caused by iron deficiency [53]. In this study, anaemia was negatively associated with household water treatment of mothers. This is because intestinal helminths and diarrhoea, which cause anaemia [16], can be killed with household water treatments methods $[5,6,54]$.

\section{Limitation of the study}

One of the limitations of our study was that differentiation between the morphologically identical species of Entamoeba was not within the scope of this study, as only conventional microscopy was used to detect the amoebae.

\section{Conclusions}

This study revealed the significant burden of IPI and anaemia in preschool children in a rural community in Northern Ethiopia. More than half of the children were infected with intestinal parasites and one in five were anaemic. IPI was higher in children with current gastro intestinal symptoms, who had diarrhoea in the previous 14 days, and who had been de-wormed. Prevalence was however, lower in households with two or more children 
aged under 5 years. To address the problem of childhood IPIs, efforts are required by designing and implementing prevention strategies, such as integrating mothers'/ guardian's education on personal and environmental hygiene into existing national health extension program.

Eating raw meat, any maternal education and any household water treatment were associated with lower prevalence ratio of anaemia. On the other hand, presence of domestic animals in the house and proper disposal of solid waste were both associated with increased risk. This study underlines the need for interventions focusing on the identified modifiable risk factors to prevent long-term morbidity and give these children the maximal opportunity for health in the future.

Hb Haemoglobin.

\section{Abbreviations}

IPIs: Intestinal parasitic infections; EDHS: Demographic and Health Survey of Ethiopia; WHO: World Health Organization; MZN: Modified Ziehl-Neelsen

\section{Acknowledgments}

We would like to thank all the children, parents, guardians and caregivers for their collaboration. The cooperation of the Tigray Regional Health Bureau and respective Health bureaus of the districts are also highly acknowledged by the authors. The authors also like to express their sincere gratitude to the health extension workers in each site for their help in data collection and communication with each mother/guardian at a household level.

\section{Authors' contributions}

AGW, TA, MT, LN, DY, KMG, JM designed the study. AGW, HTA, RC worked on the analysis and interpretation of the data. AGW, prepared the manuscript for publication. AGW, TA, MT, HTA, JM, FF, KMG, RC reviewed the manuscript for publication. All authors read and approved the final paper.

\section{Funding}

This work was funded by the European Union Project H2020-Water-5c-2015 WATERSPOUTT (GA 688928). The funders had no role in study design, data collection and analysis, decisions to publish, interpretation of the data and preparation of the manuscript for publication.

\section{Availability of data and materials}

The datasets used and analyzed during the current study are available from the corresponding author on reasonable request.

\section{Ethics approval and consent to participate}

Ethical clearance was obtained from Mekelle University; College of Health Science Institutional Review Board (IRB) [ERC 0844/2016]. Permission was obtained from the Tigray Regional Health Bureau and respective district Health Bureau. Written consent was obtained from mothers / guardians. Children with IPIs and anaemia were referred to the nearby health institutions and treated from the project fund.

\section{Consent for publication}

Not applicable.

\section{Competing interests}

We declare that we have no conflict of interest.

\section{Author details}

'Department of Medical Microbiology and Immunology, College of Health Sciences, Mekelle University, Tigray, Ethiopia. ${ }^{2}$ Department of Biology, College of Natural and Computational Sciences, Mekelle University, Tigray, Ethiopia. ${ }^{3}$ Department of Chemical and Environmental Technology, Universidad Rey Juan Carlos, C/ Tulipán s/n, 28933 Móstoles, Madrid, Spain. ${ }^{4}$ Department of Environmental Health, College of Health Sciences, School of Public Health, Mekelle University, Tigray, Ethiopia. ${ }^{5}$ Department of Physiology and Medical Physics, Royal College of Surgeons in Ireland (RCSI), Dublin 2, Ireland. ${ }^{6}$ Data
Science Centre, Royal College of Surgeons in Ireland (RCSI), Dublin 2, Ireland. ${ }^{7}$ Department of Bio Statistics, College of Health Sciences, School of Public Health, Mekelle University, Tigray, Ethiopia. ${ }^{8}$ Department of Medical Microbiology, College of Health Sciences, Aksum University, Tigray, Ethiopia.

Received: 1 October 2019 Accepted: 17 May 2020

Published online: 27 May 2020

\section{References}

1. Lobo ML, Augusto J, Antunes F, Ceita J, Xiao L, Codices V, et al. Cryptosporidium spp., Giardia duodenalis, Enterocytozoon bieneusi and other intestinal parasites in young children in Lobata Province, Democratic Republic of São Tomé and Principe. PLoS One. 2014;9(5):e97708 https://doi. org/10.1371/journal.pone.0097708.

2. Keiser J, Utzinger J. The drugs we have and the drugs we need against major helminth infections. Adv Parasitol. 2010;73:197-230.

3. Fischer Walker CL, Aryee MJ, Boschi-Pinto C, Black RE. Estimating diarrhea mortality among young children in low and middle income countries. PLoS One. 2012;7(1):e29151.

4. Keogh MB, Castro-Alférez M, Polo-López MI, Fernández Calderero I, Al-Eryani YA, Joseph-Titus C, et al. Capability of 19-L polycarbonate plastic water cooler containers for efficient solar water disinfection (SODIS): field case studies in India, Bahrain and Spain. Sol Energy. 2015;116:1-11.

5. Yaoyu F, Xiao L. Zoonotic potential and molecular epidemiology of Giardia species and giardiasis. Clin Microbiol Rev. 2011;24(1):110-40.

6. World Health Organization. Soil-transmitted helminth infections .WHO Fact Sheet, 2018. Available http://www.who.int/news-room/fact-sheets/detail/ soil-transmitted-helminth-infections.

7. Global Burden of Disease. Estimates of global, regional, and national morbidity, mortality, and aetiologies of diarrhoeal diseases: a systematic analysis for the Global Burden of Disease Study 2015. Lancet Infect Dis. 2017;17(9):909-48.

8. Thomas IV L, Zweig AP, Tosh AK. An adolescent with chronic giardiasis mimicking anorexia nervosa. Int J Adolesc Med Health. 2014;26(2):293-5.

9. Al-Mekhlafi HM, Al-Maktari MT, Jani R, et al. Burden of Giardia duodenalis infection and its adverse effects on growth of schoolchildren in rural Malaysia. PLoS Negl Trop Dis. 2013;7(10):e2516. https://doi.org/10.1371/ journal.pntd.0002516.

10. Kejo D, Petrucka PM, Martin H, Kimanya ME, Mosha TC. Prevalence and predictors of anaemia among children under 5 years of age in Arusha District, Tanzania. Pediatr Heal Med Ther. 2018;9:9-15.

11. WHO. The Global Prevalence of Anaemia in 2011. WHO Rep 2011; 48.

12. McLean E, Cogswell M, Egli I, Wojdyla D, de Benoist B. Worldwide prevalence of anaemia, WHO vitamin and mineral nutrition information system, 1993-2005. Public Heal Nutr. 2009;12(4):444-54.

13. Phiri KS, Calis JCJ, Faragher B, Nkhoma E, Ng'oma K, Mangochi B, et al. Long term outcome of severe anaemia in Malawian children. PLoS One. 2008:3(8):e2903.

14. Legason ID, Atiku A, Ssenyonga R, et al. Prevalence of Anaemia and associated risk factors among children in North-Western Uganda: a cross sectional study. BMC Hematol. 2017;17:10 https://doi.org/10.1186/s12878017-0081-0.

15. Menon MP, Yoon SS, Uganda malaria Indicator survey technical working group. Prevalence and factors associated with Anemia among children under 5 years of age--Uganda, 2009. Am J Trop Med Hyg. 2015;93(3):521-6. https://doi.org/10.4269/ajtmh.15-0102.

16. Falkingham M, Abdelhamid A, Curtis P, Fairweather-Tait S, Dye L, Hooper L. The effects of oral iron supplementation on cognition in older children and adults: a systematic review and meta-analysis. Nutr J. 2010;9:4. https://doi. org/10.1186/1475-2891-9-4

17. Cassat JE, Skaar EP. Iron in infection and immunity. Cell Host Microbe. 2013; 13(5):509-19.

18. More S, Shivkumar VB, Gangane N, Shende S. Effects of iron deficiency on cognitive function in school going adolescent females in rural area of Central India. Anemia. 2013;2013:819136.

19. FDRE CSA. Key findings health survey Ethiopia. 2016; Available from: https:// dhsprogram.com/pubs/pdf/SR241/SR241.pdf.

20. Nyantekyi LA, Legesse M, Belay M, Tadesse K, Manaye K, Macias C, et al. Intestinal parasitic infections among under-five children and maternal awareness about the infections in Shesha Kekele, Wondo genet, South Ethiopia. Ethiop J Heal Dev. 2010;24(3):185-90. 
21. Mulatu G, Zeynudin A, Zemene E, Debalke S, Beyene G. Intestinal parasitic infections among children under five years of age presenting with diarrhoeal diseases to two public health facilities in Hawassa, South Ethiopia. Infect Dis Poverty. 2015;4:49. https:/doi.org/10.1186/s40249-015-0081-x.

22. G/hiwot Y, Degarege A, Erko B. Prevalence of intestinal parasitic infections among children under five years of age with emphasis on Schistosoma mansoni in Wonji Shoa Sugar Estate, Ethiopia. PLoS One. 2014;9(10): e109793. https://doi.org/10.1371/journal.pone.0109793.

23. Aleka Y, G/egziabher S, Tamir W, Birhane M, Alemu a. prevalence and associated risk factors of intestinal parasitic infection among under five children in University of Gondar Hospital, Gondar, Northwest Ethiopia. Biomed Res Ther 2015; 2(8):347-353.

24. Kotloff KL, Nataro JP, Blackwelder WC, Nasrin D, Farag TH, Panchalingam S, et al. Burden and aetiology of diarrhoeal disease in infants and young children in developing countries (the global enteric multicenter study, GEMS): a prospective, case-control study. Lancet. 2013;382:209-22.

25. Wasihun AG, Dejene TA, Teferi M, Maruga'n J, Negash L, Yemane D, et al. Risk factors for diarrhoea and malnutrition among children under the age of 5 years in the Tigray Region of Northern Ethiopia. PLoS ONE. 2018;13(11): e0207743. https://doi.org/10.1371/journal.pone.0207743.

26. World Health Organization. Iron Deficiency Anaemia: Assessment, Prevention and Control, A guide for program managers. 2001; 114.

27. Zeibig EA. Clinical Parasitology: A Pratical Approach. Vol. 1, Elsevier. 1997. P 385.

28. Cummings $P$. The relative merits of risk ratios and odds ratios. Arch Pediatr Adolesc Med. 2019;163(5):438-45. https://doi.org/10.1001/archpediatrics.2009.31

29. Mehraj V, Hatcher J, Akhtar S, Rafique G, Beg MA. Prevalence and factors associated with intestinal parasitic infection among children in an urban slum of Karachi. PLoS One. 2008; 3 (11).

30. Tyoalumun K, Abubakar S, Christopher N. Prevalence of intestinal parasitic infections and their association with nutritional status of rural and urban preschool children in Benue state, Nigeria. Int J MCH AIDS. 2016;5(2):146-52

31. Cañete R, Díaz MM, Avalos García R, Laúd Martinez PM, Manuel PF. Intestinal parasites in children from a day Care Centre in Matanzas City, Cuba. PLoS One. 2012;7(12):e51394.

32. Ngui R, Lim YAL, Kin LC, Chuen CS, Jaffar S. Association between anaemia, iron deficiency anaemia, neglected parasitic infections and socioeconomic factors in rural children of West Malaysia. PLoS Negl Trop Dis. 2012;6(3):1-8.

33. Gebretsadik D, Metaferia Y, Seid A, Fenta GM, Gedefie A. Prevalence of intestinal parasitic infection among children under 5 years of age at Dessie referral hospital: cross sectional study. BMC Res Notes BioMed Central. 2018; 11(1):771.

34. Beyene G, Tasew H. Prevalence of intestinal parasite, Shigella and Salmonella species among diarrheal children in Jimma health center, Jimma Southwest Ethiopia: a cross sectional study. Ann Clin Microbiol Antimicrob. 2014;13(1):1-7

35. Zemene T, Shiferaw MB. Prevalence of intestinal parasitic infections in children under the age of 5 years attending the Debre Birhan referral hospital, north Shoa, Ethiopia. BMC Res Notes. 2018;11(1):1-6.

36. Gizaw Z, Adane T, Azanaw J, Addisu A, Haile D. Childhood intestinal parasitic infection and sanitation predictors in rural Dembiya, northwest Ethiopia. Environ Health Prev Med. ; 2018; 23 (1):1-10.

37. Achi EC, Njoku OO, Nnachi AU, Efunshile AM, Mbah JO, Aghanya IN, et al. Prevalence of intestinal parasitic infections among under five children in Abakaliki local government area of Ebonyi state. Eur J Pharm Med Res. 2017; 4(4):218-22.

38. Mesgarian F, Sofizadeh A, Shoraka HR, Rahimi HR, Hesari A, et al. Prevalence of intestinal parasite infections among children in the day care centers of Gonbad-e Kavus County, north-eastern Iran, Zahedan. J Res Med Sci. 2017; 19(10):e11633.

39. Ojja S, Kisaka S, Ediau M, et al. Prevalence, intensity and factors associated with soil-transmitted helminths infections among preschool-age children in Hoima district, rural western Uganda. BMC Infect Dis. 2018;18(1):1-12.

40. Wafa A.I. AL-Megrin, 2015. Assessment the prevalence of intestinal parasites and associated risk factors among preschool children in Riyadh, Saudi Arabia. Res J Parasitol, 10: 31-41.

41. Alyousefi NA, Mahdy MAK, Mahmud R, Lim YAL. Factors associated with high prevalence of intestinal protozoan infections among patients in Sana'a City, Yemen. PLoS ONE. 2011;6(7):e22044 https://doi.org/10.1371/journal. pone.0022044

42. Shumbej T, Belay T, Mekonnen Z, Tefera T, Zemene E, Ferron ES. Soiltransmitted helminths and associated factors among pre-school children in
Butajira Town, south-central Ethiopia: A community-based cross-sectional study. PLoS One. 2015; 10 (8).

43. Firdu T, Abunna F, Girma M. Intestinal Protozoal parasites in diarrheal children and associated risk factors at Yirgalem hospital. Ethiopia: A CaseControl Study Int Sch Res Not. 2014;2014:1-8.

44. Mulatu G, Zeynudin A, Zemene E, Debalke S, Beyene G. Intestinal parasitic infections among children under five years of age presenting with diarrhoeal diseases to two public health facilities in Hawassa, South Ethiopia. Infect Dis Poverty. 2015;4:49.

45. Mondal D, Petri WA, Sack RB, Kirkpatrick BD, Haque R. Entamoeba histolytica-associated diarrheal illness is negatively associated with the growth of preschool children: evidence from a prospective study. Trans $R$ Soc Trop Med Hyg. 2006;100(11):1032-8.

46. Zemene, T, Shiferaw, MB. Prevalence of intestinal parasitic infections in children under the age of 5 years attending the Debre Birhan referral hospital, North Shoa, Ethiopia. BMC Res Notes. 2018;11(58). https://doi.org/ 10.1186/s13104-018-3166-3.

47. Vargas M, Gascón J, Casals C, Schellenberg D, Urassa H, Kahigwa E, et al. Etiology of diarrhea in children less than five years of age in Ifakara. Tanzania Am J Trop Med Hyg. 2004;70(5):536-9.

48. Brooker S, Singhasivanon P, Waikagul J, Supavej S, Kojima S, Takeuchi T, et al. Mapping soil-transmitted helminths in Southeast Asia and implications for parasite control. Southeast Asian J Trop Med Public Health. 2003;34(1):24-36.

49. Appleton CC, Gouws E. The distribution of common intestinal nematodes along an altitudinal transect in KwaZulu-Natal. South Africa Ann Trop Med Parasitol. 1996;90(2):181-8.

50. Machicado JD, Marcos LA, Tello R, Canales M, Terashima A, Gotuzzo E. Diagnosis of soil-transmitted helminthiasis in an Amazonic community of Peru using multiple diagnostic techniques. Trans R Soc Trop Med Hyg. 2012;106(6):333-9.

51. Tefera E, Mohammed J, Mitiku H. Intestinal helminthic infections among elementary students of Babile town, eastern Ethiopia. Pan Afr Med J. 2015;20:1-10.

52. HORTON J. Albendazole: a review of anthelmintic efficacy and safety in humans. Parasitology.2000; 121 (S1):S113.

53. Kiani H, Haghighi A, Rostami A, Azargashb E, Tabaei Sjs, Solgi A, et al. Prevalence, Risk Factors and Symptoms Associated To Intestinal Parasite Infections Among Patients With Gastrointestinal Disorders in Nahavand Western Iran. Rev Inst Med Trop Sao Paulo. 2016; 58: 42. doi:https://doi.org/ 10.1590/S1678-9946201658042.

54. Fagerli K, Trivedi KK. Sodha S V, Blanton E, Ati a, Nguyen T, et al. HHS Public Access. 2018;145(15):3294-302.

55. Freeman MC, Quick RE, Abbott DP, Ogutu P, Rheingans R. Increasing equity of access to point-of-use water treatment products through social marketing and entrepreneurship: a case study in western Kenya. J Water Health. 2009;7(3):527-34.

56. Sodha SV, Menon M, Trivedi K, Ati A, Figueroa ME, Ainslie R, et al. Microbiologic effectiveness of boiling and safe water storage in South Sulawesi. Indonesia J Water Health. 2011;9(3):577-85.

57. Gari T, Loha E, Deressa W, Solomon T, Atsbeha H, Assegid M, et al. Anaemia among children in a drought affected community in south-central Ethiopia. PLoS One.2017; 12(3).

58. Kisiangani I, Mbakaya C, Makokha A. Prevalence of Anaemia and associated factors among preschool children (6-59 months) in Western Province. Kenya Public Heal Prev Med. 2015;1(1):28-32.

59. Carvalho AGC, de Lira PIC, Barros M de FA, Aléssio MLM, Lima M de C, Carbonneau MA, et al. Diagnóstico de-anaemia por defi ciência de ferro em crianças do Nordeste do Brasil. Rev Saude Publica 2010; 44 (3):513-519.

60. Gebreegziabiher G, Etana B, Niggusie D. Determinants of Anaemia among children aged 6-59 months living in Kilte Awulaelo Woreda. Northern Ethiopia Anaemia. 2015;2014

61. Kawo KN, Asfaw ZG, Yohannes N. Multilevel analysis of determinants of Anemia prevalence among children aged 6-59 months in Ethiopia: classical and Bayesian approaches. Anemia. 2018;2018:3087354.

62. Luciana PL, Filho MB, Israel Pedro LC. De, Osório MM, I MBF, Israel P, et al. prevalence of anaemia and associated factors in children aged 6-59 months in Pernambuco, northeastern Brazil. Rev Saúde Pública. 2011;45(3):1-8.

63. Osazuwa F, Ayo OM, Imade P. A significant association between intestinal helminth infection and anaemia burden in children in rural communities of Edo state. Nigeria N Am J Med Sci. 2011;3(1):30-4.

64. Khan JR, Awan N, Misu F. Determinants of anaemia among 6-59 months aged children in Bangladesh: evidence from nationally representative data BMC Pediatr. 2016;16(1):1-12. 
65. Tine RC, Faye B, Ndiaye JL, Ndour CT, Magnussen P, Bygbjerg IC, et al. Prevalence of intestinal parasites, anaemia and anthropometric status among children under five years of age in Lamarame (Senegal). Am J Tropical Med Hygiene. 2010;83(5, suppl):93.

66. Semedo RML, Santos MMAS, Baião MR, Luiz RR, Da Veiga GV. Prevalence of Anaemia and associated factors among children below five years of age in Cape Verde, West Africa. J Heal Popul Nutr. 2014;32(4):646-57.

67. Nyaruhucha CN, Mamiro PS, Kerengi AJ. Prevalence of anaemia and parasitic infections among under five children in Simanjiro District, Tanzania Tanzan. Health Res Bull. 2005;7(1):35-9.

68. Mahmud MA, Spigt M, Mulugeta Bezabih A, López Pavon I, Dinant G-J, Blanco VR. Risk factors for intestinal parasitosis, anaemia, and malnutrition among school children in Ethiopia. Pathog Glob Health. 2013;107(2):58-65.

69. Hajison PL, Mwakikunga BW, Mathanga DP, Feresu SA. Seasonal variation of malaria cases in children aged less than 5 years old following weather change in Zomba district, Malawi Malar. J BioMed Central. 2017;16:1-12. https://doi.org/10.1186/s12936-017-1913-x.

70. Verhagen LM, Incani RN, Franco CR, Ugarte A, Cadenas Y, Sierra Ruiz Cl, et al. High malnutrition rate in Venezuelan Yanomami compared to Warao Amerindians and creoles: significant associations WITH intestinal parasites and Anaemia. PLoS One. 2013;8(10):e77581 https://doi.org/10.1371/journal. pone.0077581

71. Ojoniyi OO, Odimegwu CO, Olamijuwon EO, Akinyemi JO. Does education offset the effect of maternal disadvantage on childhood anaemia in Tanzania ? Evidence from a nationally representative cross-sectional study. BMC Pediatr. 2019:19:1-10.

72. Moshe G, Amitai Y, Korchia G, Korchia L, Tenenbaum A, Rosenblum J, et al. Anemia and Iron deficiency in children : association with red meat and poultry consumption. JPGN. 2013;57:722-7. https://doi.org/10.1097/MPG. 0b013e3182a80c42.

\section{Publisher's Note}

Springer Nature remains neutral with regard to jurisdictional claims in published maps and institutional affiliations.

Ready to submit your research? Choose BMC and benefit from:

- fast, convenient online submission

- thorough peer review by experienced researchers in your field

- rapid publication on acceptance

- support for research data, including large and complex data types

- gold Open Access which fosters wider collaboration and increased citations

- maximum visibility for your research: over $100 \mathrm{M}$ website views per year

At $\mathrm{BMC}$, research is always in progress.

Learn more biomedcentral.com/submissions 